$168 \ldots \ldots$ To Stack

Y-2050

ELECTRON-BEAM, MULTIPASS, WIRE-FED WELDING OF TYPE 5083

ALUMINUM

J. L. Murphy

July 1976

UNION

CARBIDE

\section{OAK RIDGE Y-12 PLANT}

OAK RIDGE. TENNFSSEE

prepared for the U.S. ENERGY RESEARCH AND DEVELOPMENT ADMINISTRATION under U.S. GOVERNMENT Contract W-7405 eng 26 


\section{DISCLAIMER}

This report was prepared as an account of work sponsored by an agency of the United States Government. Neither the United States Government nor any agency Thereof, nor any of their employees, makes any warranty, express or implied, or assumes any legal liability or responsibility for the accuracy, completeness, or usefulness of any information, apparatus, product, or process disclosed, or represents that its use would not infringe privately owned rights. Reference herein to any specific commercial product, process, or service by trade name, trademark, manufacturer, or otherwise does not necessarily constitute or imply its endorsement, recommendation, or favoring by the United States Government or any agency thereof. The views and opinions of authors expressed herein do not necessarily state or reflect those of the United States Government or any agency thereof. 


\section{DISCLAIMER}

Portions of this document may be illegible in electronic image products. Images are produced from the best available original document. 


\section{Printed in the United States of America. Available from National Technical Information Service \\ U.S. Department of Commorco \\ 5285 Port Royal Road, Springfield, Virginia 22161}

Price: Printed Copy $\$ 3.50$; Microfiche $\$ 2.25$

This report was prepared as an account of work sponsored by the United States Government. Neither the United States nor the Energy Research and Development Administration/United States Nuclear Regulatory Commission, nor any of their employees, nor any of their contractors, subcontractors, or their employees, makes any warranty, express or implied, or assumes any legal liability or responsibility for the accuracy, completeness or usefulness of any information, apparatus, product or process disclosed, or represents that its use would not infringe privately owned rights. 
Date of Issue: July 29, 1976

Report Number: Y-2050

Distribution Category: UC-38

\title{
ELECTRON-BEAM, MULTIPASS, WIRE-FED WELDING \\ OF TYPE 5083 ALUMINUM
}

\author{
J. L. Murphy \\ Metallurgical Development Department \\ Y-1.2 Development Division
}

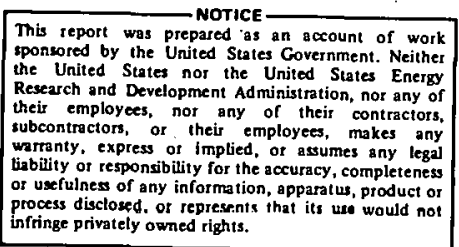

infringe privately owned rights.

Oak Ridge $Y$-12 Plant

P. O. Box Y, Oak Ridge, Tennessee 37830

Prepared for the US Energy Research

and Development Administration

Under US Government Contract W. 7405-eng-26 


\begin{abstract}
The versatility and advantages of electron-beam, multipass, wire-fed welding were demonstrated on 5.33 and 1.52-mm (210 and 60-mil)-thick Type 5083 aluminum cylinders by making full-penetration welds that had controlled inner distortion and minimum porosity.

A comparison was made between the mechanical properties of gas tungsten-arc welds; electron-beam, autogenous welds, and electron-beam, wire-fed welds. The yield strength of the electron-beam, wire-fed welds compared favorably with the yield strength of the arc welds and autogenous, electron-beam welds. The tensile strength of the electron-beam, wire-fed welds is reduced, because of the depletion of some magnesium from the weld, resulting in a weld-joint efficiency of approximately $74 \%$. A determination was made of the loss of magnesium from the weld that resulted from electron-beam, multipass, autogenous and gas tungsten-arc welding.
\end{abstract}




\section{CONTENTS}

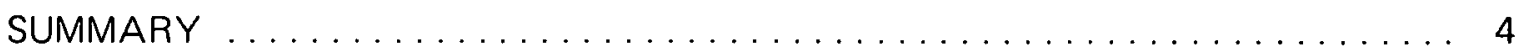

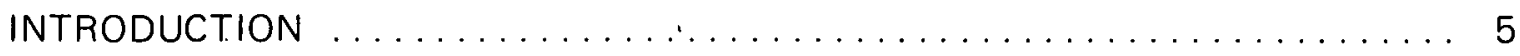

ELECTRON-BEAM, MULTIPASS, WIRE-FED WELDING $\ldots \ldots \ldots \ldots \ldots \ldots$

Experimental Work ............................... 6

Techniques for Welding 5.33-mm (210-mil)-Thick Cylinders . . . . . . . . . 6

Mechanical Properties of Wire-Fed Welds . . . . . . . . . . . . . . . . . . . 8

Magnesium Content of Wire-Fed Welds ..................... 8

Techniques for Welding 1.5-mm (60-mil)-Thick Cylinders ........... 9

Comparison of Mechanical Properties to the Welding Method $\ldots \ldots \ldots \ldots .9$

Comparison of Magnesium Losses to the Welding Method ............... 11

Porosity in Multipass, Wire-Fed Welds . . . . . . . . . . . . . . . . . 14

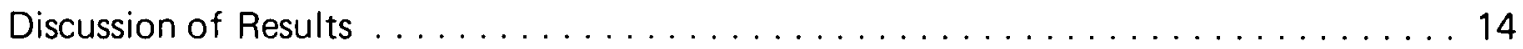

REFERENCES ....................................... 16 


\section{SUMMARY}

Electron-beam, multipass, wire-fed welds were made on Type 5083 aluminum sylinders that had a 5.33-mm (210-mil) or $1.52-\mathrm{mm}(60-\mathrm{mil})$ wall thickness. Preweld compensation for weld distortion was determined for the 5.33-mm-thickness aluminum cylinder. Mechanical properties of the multipass welds were obtained and related to the magnesium content in the welds. A comparison was made of the mechanical properties of gas tungsten-arc welds, electron-beam single-pass autogenous welds, and electron-beam wire-fed welds. 


\section{INTRODUCTION}

Multipass, wire-fed, electron-beam welding makes it possible to achieve full-penetration welds in a variety of thicknesses and still maintain some control over material chemistry, distortion, backside temperature, and weld structure. Root defects, cold shuts, porosity, and variation in penetration are problems that can result from an autogenous, single-pass, electron-beam weld in aluminum and other metals. $(1-8)$ It was previously described how incomplete fusion and spiking can be avoided by using a multipass welding method. (5,9-11) Development of a dial-switch-programmed wire feeder and positioner for electron-beam welding has been reported. (9) A computerized electron-beam and wire-feeding system has also been reported. $(11.12)$ In the present work, electron-beam, multipass, wire-fed welding has been evaluated on 5.33 and $1.52-\mathrm{mm}$ ( 210 and 60-mil)-thick Type 5083 aluminum. 


\section{ELECTRON-BEAM, MULTIPASS, WIRE-FED WELDING}

\section{EXPERIMENTAL WORK}

\section{Techniques For Welding 5.33-mm (210-mil)-Thick Cylinders}

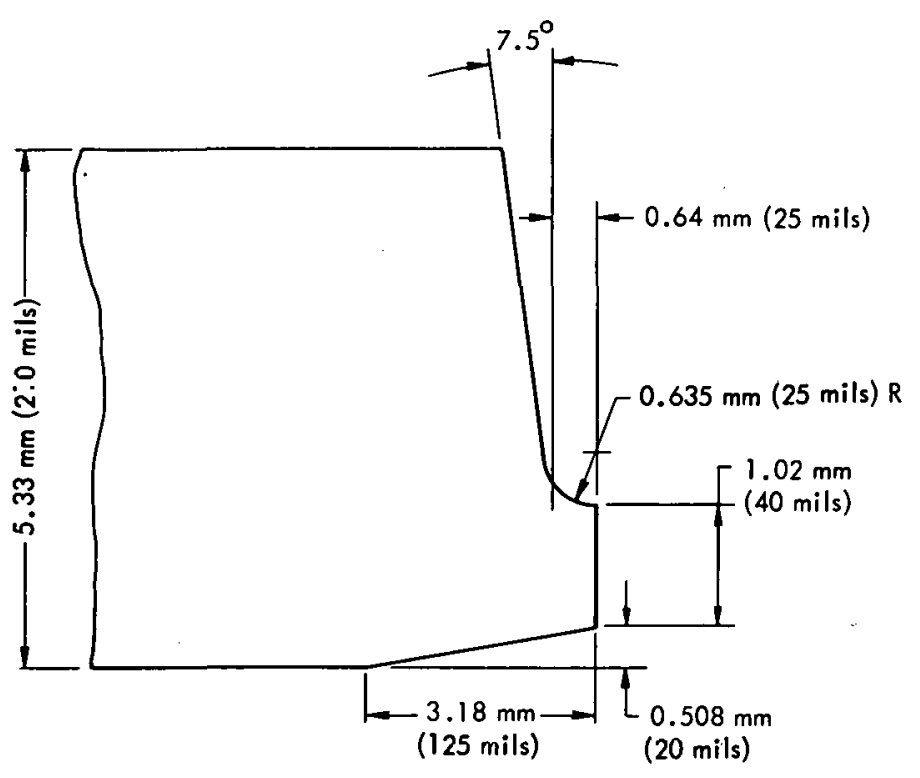

Figure 1. JOINT GEOMETRY FOR ELECTRON-BEAM, WIRE-FED WELDING OF TYPE 5083 ALUMINUM. (Joint Compensated for Root Distortion)
The weld-joint details that were established for welding 5.33-mmthick aluminum are outlined in Figure 1. Table 1 gives the welding parameters. The resulting welds are illustrated in Figure 2. View a, of Figure 2, shows root distortion of the wold while View b shows an improved root configuration brought about by using a 0.508 by $3.18-\mathrm{mm}$ (20 by $125-\mathrm{mil}$ ) chamfer at the root of the joint illustrated in Figure 1. Table 1 shows that an duiogenous weild was made on the $1.02-\mathrm{mm}(40-\mathrm{mil})$ root width. Five wire-fed weld passes were used to complete the weld. Welding parameters were held constant for the five weld passes except for one change in the part travel speed and one change in wire feed rate. Figure 3 shows a dimensional distortion of a welded cylinder that had the joint preparation that is indicated in Figure 1. The eylinder was welded such that it would not be restrained from distorting. The dimensions would change with inside restraint.

Table 1

WELDING PARAMETERS FOR ELECTRON-BEAM, WIRE-FED

WELDING OF TYPE 5083 ALUMINUM

(Filler Metal was 0.76-mm (.30.mil). - nipmeter Type 5356 Aluminum]

\begin{tabular}{|c|c|c|c|c|c|c|c|}
\hline \multirow[b]{2}{*}{ Weld Pass (1) } & \multirow{2}{*}{$\begin{array}{c}\text { Beam } \\
\text { Voltage } \\
\text { (kV) }\end{array}$} & \multirow{2}{*}{$\begin{array}{c}\text { Beam } \\
\text { Caurrent } \\
\text { (mA) }\end{array}$} & \multicolumn{2}{|c|}{ Wold Sppeod } & \multirow{2}{*}{$\begin{array}{c}\text { Beam } \\
\text { Forus (2) } \\
\text { (mA) }\end{array}$} & \multicolumn{2}{|c|}{ Wiru Speed } \\
\hline & & & (ipm) & $(\mathrm{mm} / \mathrm{s})$ & & $\overline{(i p m)}$ & $(\mathrm{mm} / \mathrm{s})$ \\
\hline 1 & 75 & 5 & 20 & 8.45 & 430 & 0 & 0 \\
\hline 2 & 75 & 8 & 20 & 8.45 & 465 & 20 & 8.48 \\
\hline 3 & 75 & 8 & 14 & 5.93 & 455 & 30 & 12.69 \\
\hline 4 & 76 & 0 & 14 & 5.92 & $4 b 5$ & 30 & 12.69 \\
\hline 6 & 75 & 8 & 14 & 5.92 & 455 & 30 & 12.69 \\
\hline 6 & 75 & 8 & 14 & 5.92 & 455 & 30 & 12.69 \\
\hline
\end{tabular}

(1) An R-40 gun was used with the filament in the flush position.

(2) Sharp focus at the root of the joint at $1.0 \mathrm{~mA}$ was $390 \mathrm{~mA}$. 


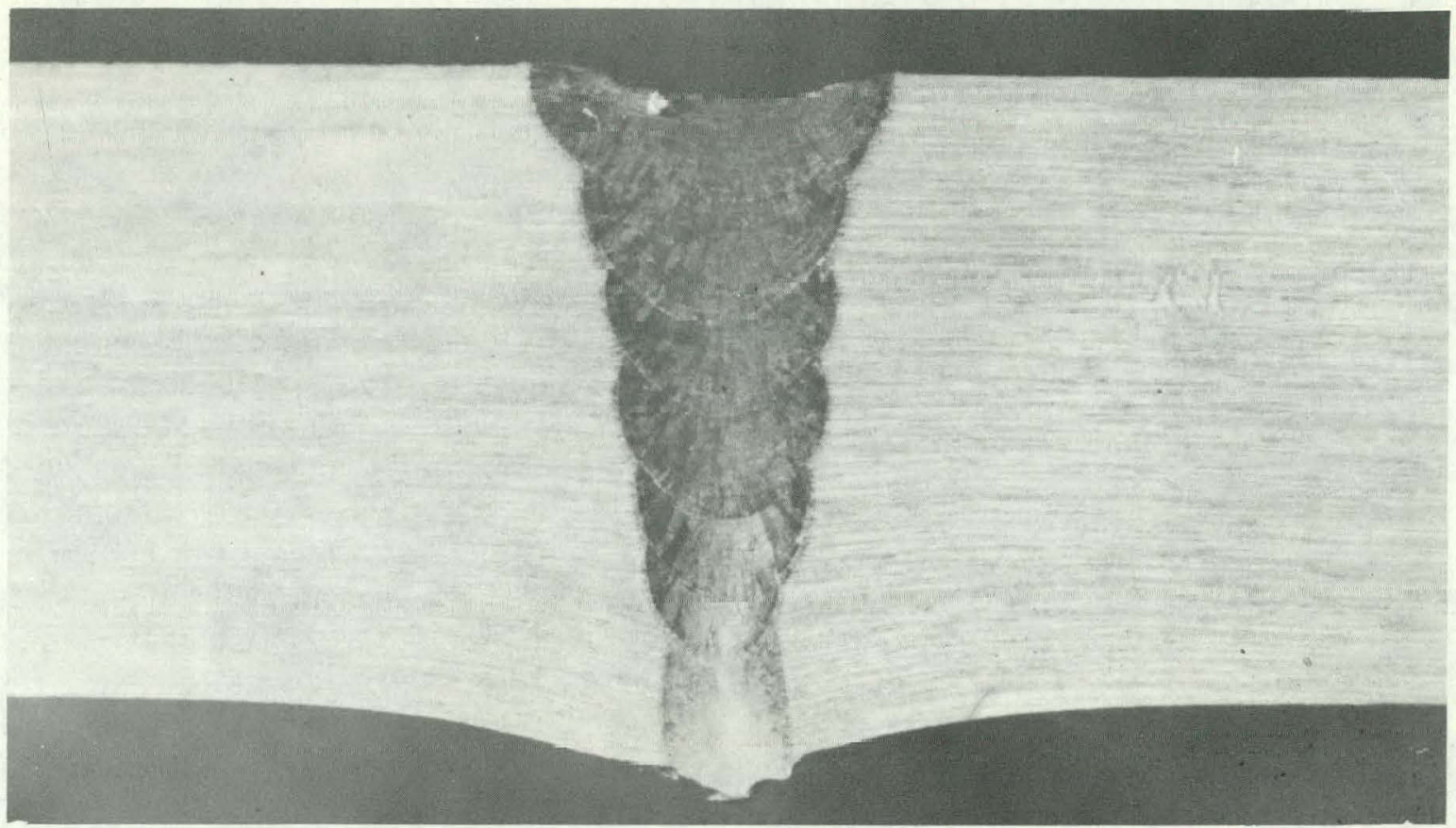

(a) Root Distortion of Weld.

MS-72-0584-11

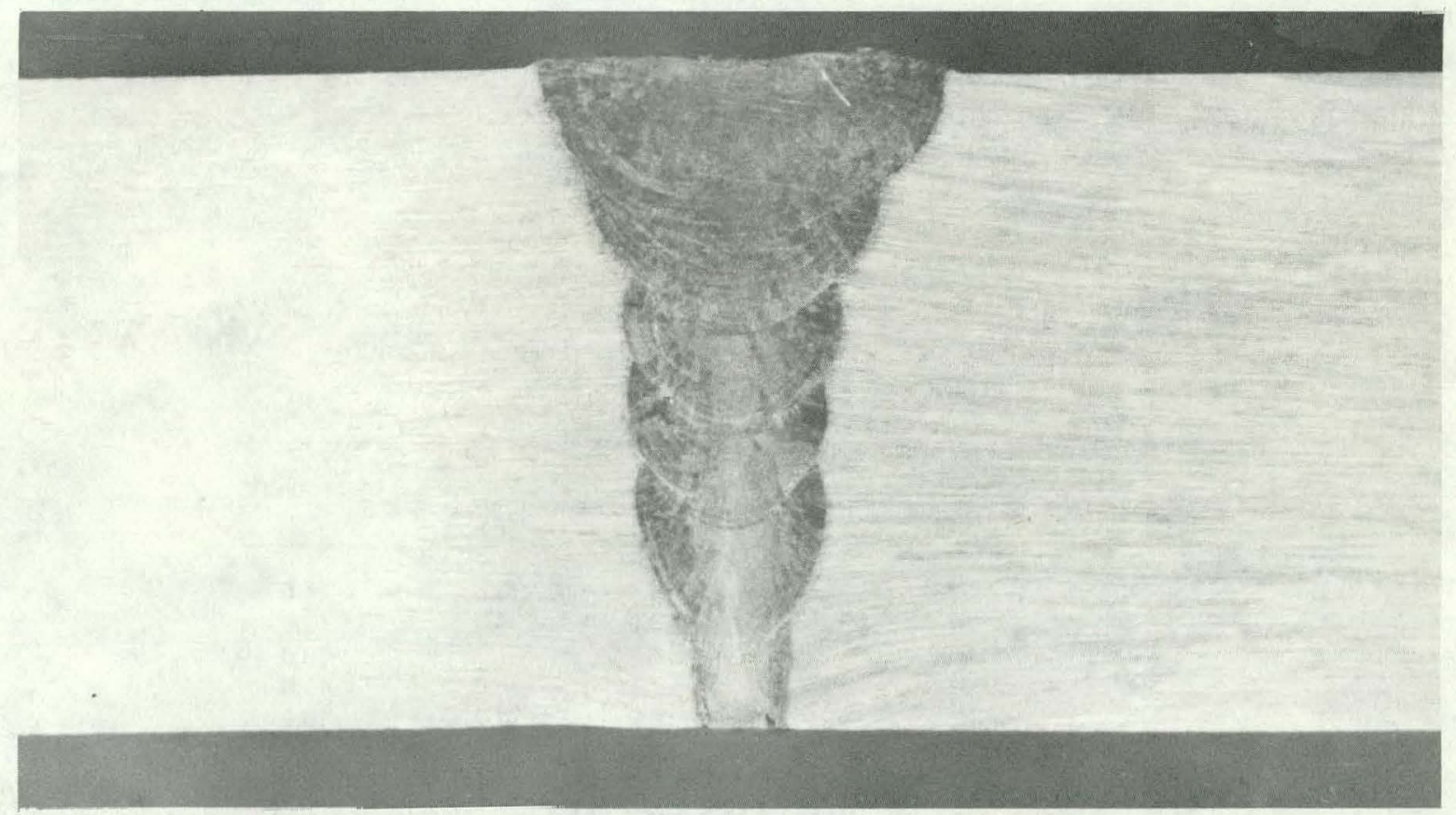

(b) Improved Root Configuration.

MS-72-0584-14

Figure 2. MULTIPASS, WIRE-FED, ELECTRON-BEAM WELDS IN 5083 ALUMINUM ALLOY. (View b Shows Root Shape Improved by Using Joint Geometry Detailed in Figure $1 ; 10 \mathrm{X}$ ) 


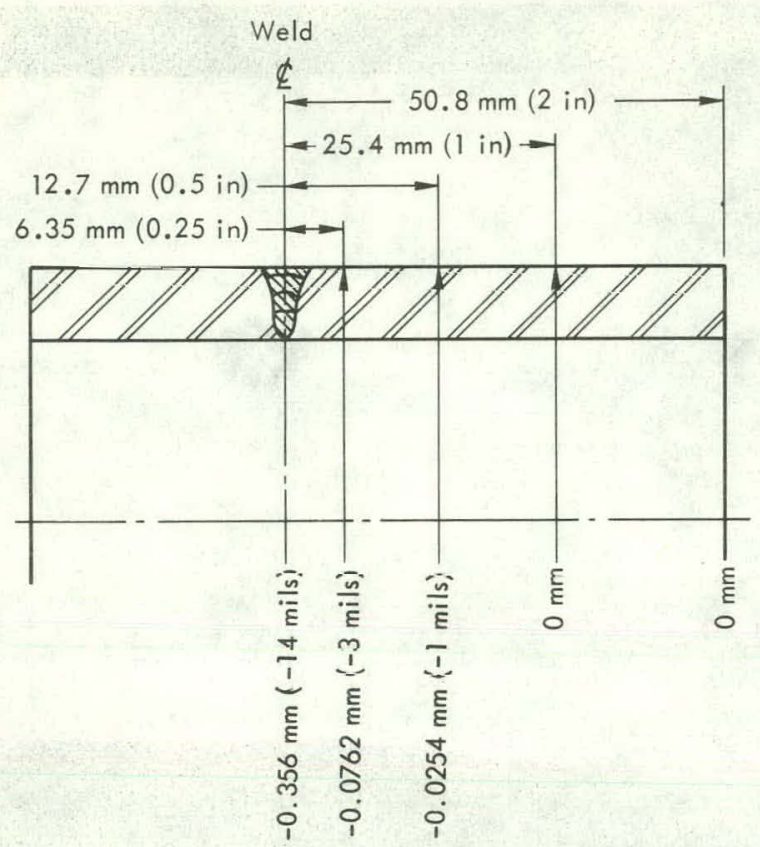

Figure 3. DIMENSIONAL-DISTORTION MEASUREMENTS OF A 152.4-mm (6-in)-DIAMETER TYPE 5083 ALUMINUM CYLINDER THAT WAS MULTIPASS WELDED. (A Minus Sign Represents Inward Diametrical Distortion)

\section{Mechanical Properties of Wire-Fed Welds}

Table 2 lists the mechanical properties of electron-beam, multipass, wire-fed welds in Type 5083-0 aluminum. Compensated welds (see Figure 2, View b) had an ultimate tensile strength of $255.1 \mathrm{MPa}$ (37 ksi) and a yield strength of approximately $134.5 \mathrm{MPa}$ (19.5 ksi). The uncompensated welds (see Figure 2, View a) had an ultimate tensile strength of approximately 248.2 MPa $(36 \mathrm{ksi})$ and a yield strength of approximately $141.4 \mathrm{MPa}$ (20.5 ksi). Minimum tensile and yield strengths of arc welds have been reported as 275.8 and $165.5 \mathrm{MPa}$ (40 and $24 \mathrm{ksi}),(13)$ respectively. The greater loss of magnesium in the electronbeam, multipass, wire-fed weld results in a reduction in strength.

\section{Magnesium Content of Wire-Fed Welds}

Electron microprobe values were taken from scans through the center of the electron-beam, multipass weld, as noted in

Figure 4. The loss of magnesium in respective weld passes is shown The autogenous weld in the root of the joint had an average of $2.5 \%$ magnesium, while the wire-fed welds had approximately $1.5 \%$ magnesium.

Table 2

TYPICAL AS-WELDED TENSILE PROPERTIES OF A MULTIPASS, ELECTRON-BEAM WELD IN TYPE 5083 ALUMINUM WITH TYPE 5356 ALUMINUM FILLER

\begin{tabular}{ccccccc}
\hline \multirow{2}{*}{ Specimen (1) } & \multicolumn{2}{c}{ Tensile Strength } & & \multicolumn{2}{c}{ Yield Strength(2) } & Elongation (3) \\
\cline { 2 - 2 } & (ksi) & (MPa) & & (ksi) & (MPa) & (\%) \\
\hline 1 & 37.0 & 255.1 & 19.4 & 133.8 & 11.0 \\
2 & 37.0 & 255.1 & 19.9 & 137.2 & 12.0 \\
3 & 37.1 & 255.8 & 19.1 & 131.7 & 13.0 \\
4 & 36.9 & 254.4 & 21.1 & 145.5 & 11.0 \\
5 & 35.1 & 242.0 & 19.9 & 137.2 & 10.0 \\
6 & 35.9 & 247.5 & 20.4 & 140.7 & 10.0 \\
\hline
\end{tabular}

(1) Type T4 spccimens woro transverse to the weld Weld-root reinforcement was not removed from Specimens 1-3 (see View a, Figure 2); weld-root reinforcement was removed from Specimens 4-6 by premachined compensation (see View b, Figure 2).

(2) At $0.2 \%$ offset.

(3) In a 25.4-mm (1-in) gage length. 


\section{Techniques for Welding 1.5-mm (60-mil)- Thick Cylinders}

Electron-beam, multipass, wire-fed welding of $1.52-\mathrm{mm}$ (60-mil)-thick aluminum was evaluated to determine if an improved root contour and reduced porosity could be achieved when compared to one-pass, autogenous, electron-beam or gas tungsten-arc welds. (The multipass welding method also offers precise control of the energy input to the root weld pass.) A root width that could successfully be welded was selected and the remainder of the joint was filled with welding wire. Figure 5, Joint Geometry A, shows the weld-joint details that were developed. The welding procedure is given in Table 3; a typical wire-fed weld is shown in Figure 6. The first autogenous weld was followed by two wire-fed welds using $380-\mu \mathrm{m}$ (15-mil)-diameter wire. Techniques and equipment were developed to feed the small-diameter wire. $(9,10)$ It may be noticed in Table 3 that the electron beam was oscillated longitudinal to the welding direction during the autogenous weld and transverse to the weld during the wire-fed welds. Electron-beam oscillation for the root weld helped to prevent burn through and resulted in a smoother inside weld surface. Transverse oscillation was useful on the thin aluminum to sweep the electron beam wide enough to fuse the side walls of the groove of the weld joint.

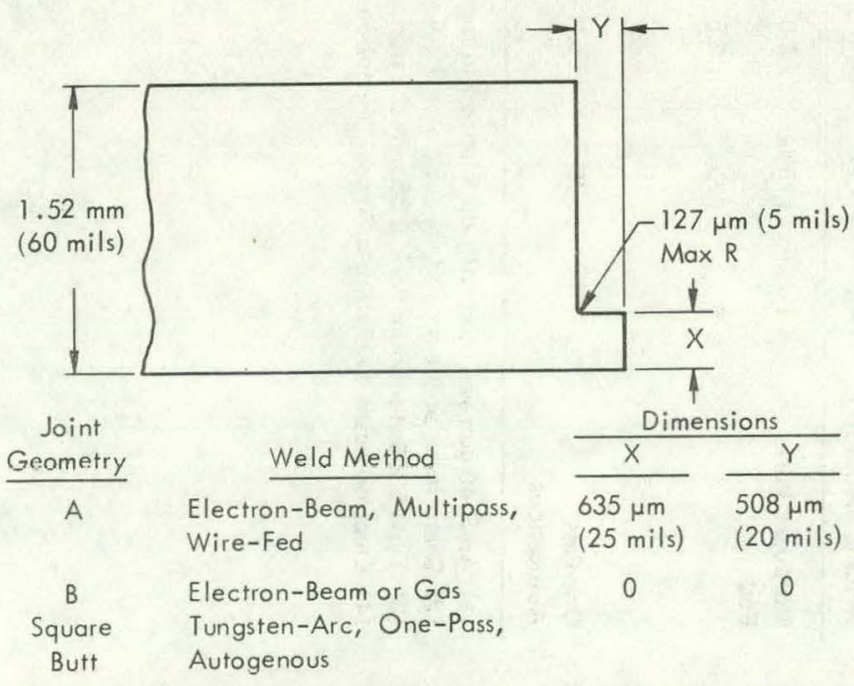

Figure 5. JOINT GEOMETRIES FOR ELECTRON-BEAM WELDING OF TYPE 5083 ALUMINUM.

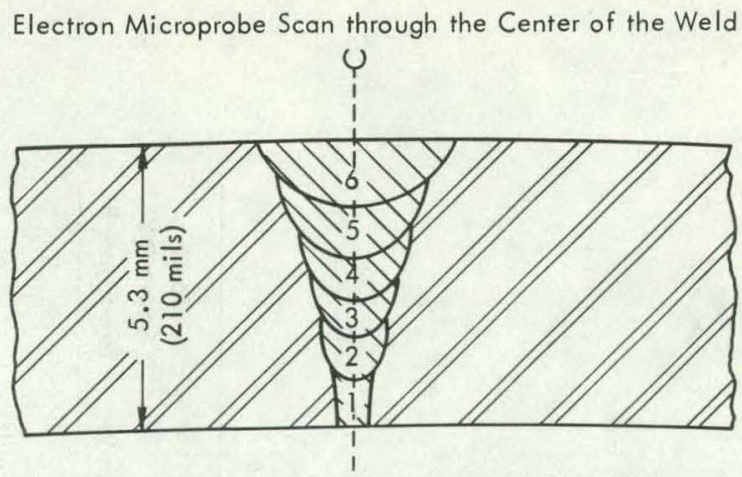

Pass 1 Welded at $28,600 \mathrm{~J} / \mathrm{mm}(1125 \mathrm{~J} / \mathrm{in})$ of weld. Passes $2-6$ Welded at $65,200 \mathrm{~J} / \mathrm{mm}(2570 \mathrm{~J} / \mathrm{in})$ of weld.

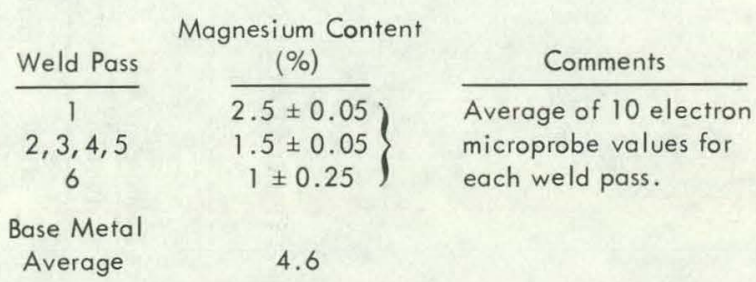

Figure 4. AVERAGE VALUES FOR THE MAGNESIUM CONTENT OF AN ELECTRON-BEAM, MULTIPASS, WIRE-FED WELD IN TYPE 5083 ALUMINUM WITH TYPE 5356 ALUMINUM WIRE.

\section{Comparison of Mechanical Proper- ties to the Welding Method}

Mechanical properties of one-pass, autogenous, electron-beam and gas tungsten-arc welds were obtained for comparison to electron-beam, wire-fed welds. Figure 7 shows a cross section of a gas tungsten-arc weld that was made on a joint that had a square-butt geometry. Copper chill rings were used at the weld joint, and they were spaced a total of 3.18 $\mathrm{mm}$ (125 mils) on the cylinders. A cross section of an autogenous, electron-beam weld that was made on a joint that had a square-butt 
Table 3

NELDING PARAMETERS FOR ELECTRON-BEAM WELDING OF TYPE 5083 ALUMINUM [1.52-mm (60-mil) Wall Thickness]

\begin{tabular}{|c|c|c|c|c|c|c|c|c|c|c|}
\hline Welding Method (1) & $\begin{array}{l}\text { Welc } \\
\text { Pass }\end{array}$ & $\begin{array}{c}\text { Beam } \\
\text { Voltage } \\
(\mathrm{kV})\end{array}$ & $\begin{array}{l}\text { Beam } \\
\text { Jurrent } \\
\text { (mA) }\end{array}$ & (ipm) & $(\mathrm{mm} / \mathrm{s})$ & $\begin{array}{l}\text { Beam } \\
\text { Focus }(2) \\
(m A)\end{array}$ & (ipm) & $(\mathrm{mm} / \mathrm{s})$ & Beam Oscillation (4) & $\begin{array}{c}\text { Joint } \\
\text { Geometry } \\
\text { (see Figure 5) }\end{array}$ \\
\hline \multirow[t]{3}{*}{$\begin{array}{l}\text { Multipass, Wire- } \\
\text { Fed }\end{array}$} & 1 & 75 & 3.0 & 35 & 14.8 & 370 & 0 & 0 & $\begin{array}{l}\text { Harmonic } Y \\
2.54 \mathrm{~mm}(100 \text { mils })\end{array}$ & \\
\hline & 2 & 75 & 2.5 & 10 & 4.2 & 370 & 25 & 12.7 & $\begin{array}{l}\text { Harrmonic } X \\
1.0 \mathrm{~mm}(40 \text { mils })\end{array}$ & A \\
\hline & 3 & 75 & 2.5 & 10 & 4.2 & 370 & 25 & 12.7 & $\begin{array}{l}\text { Harmonic } X \\
1.0 \mathrm{~mm}(40 \mathrm{mils})\end{array}$ & \\
\hline $\begin{array}{l}\text { One-Pass, } \\
\text { Autogenous }\end{array}$ & 1 & 75 & 5.0 & 35 & 14.8 & 370 & 0 & 0 & $\begin{array}{l}\text { Harmonic } Y \\
2.54 \mathrm{~mm}(100 \text { mils })\end{array}$ & B \\
\hline
\end{tabular}

(1) An R-40 gun was used with the filament in the flus? position.

(2) Sharp focus at the root of the joint at $1.2 \mathrm{~mA}$ was $370 \mathrm{~mA}$.

(3) Type 5356 eluminum wire, $0.38 \mathrm{~mm}$ ( $15 \mathrm{mils}$ ) in diameter, was used.

(4) Electron-beem oscillation is $60 \mathrm{cps}$. Dimensions are the length or width of the oscillated beam. 


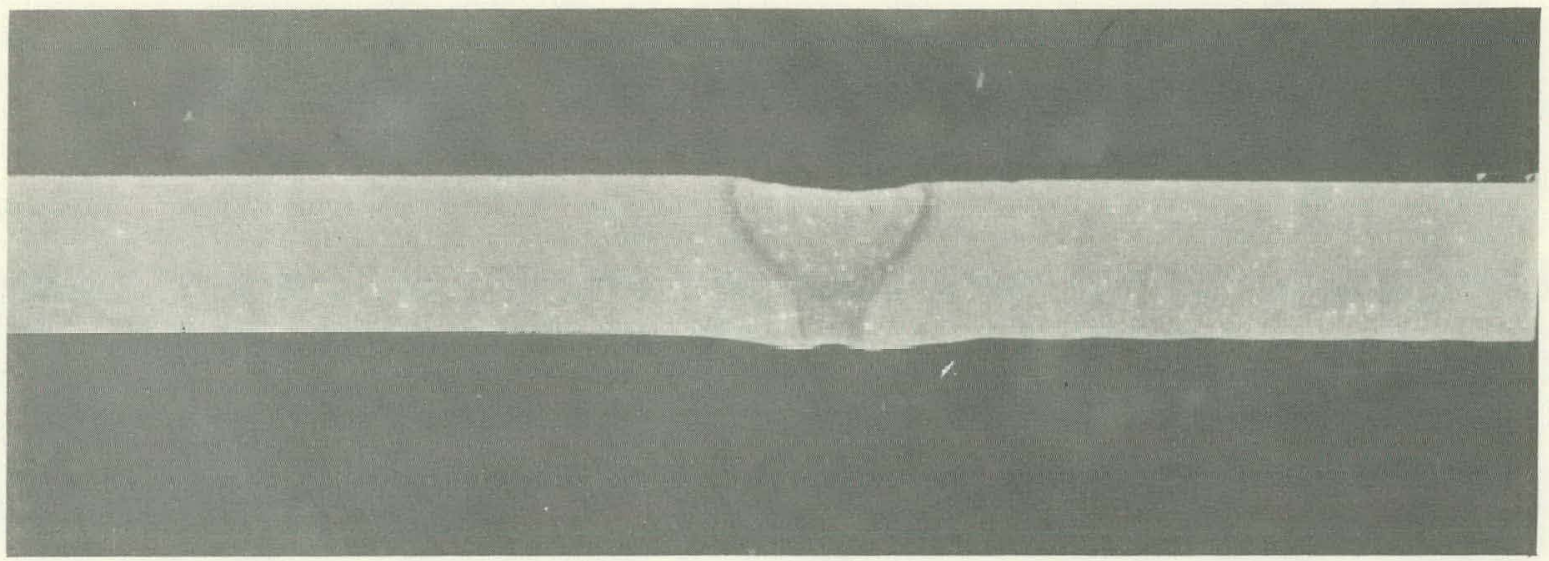

Figure 6. THREE-PASS, ELECTRON-BEAM WELD IN 1.52-mm (60-mil)-THICK TYPE 5083 ALUMINUM. (Root Pass was Autogenous Followed by Two Wire-Fed Passes Using Type 5356 Aluminum Wire; Weld-Joint Details are Shown in Figure 5, Geometry A; 10X)

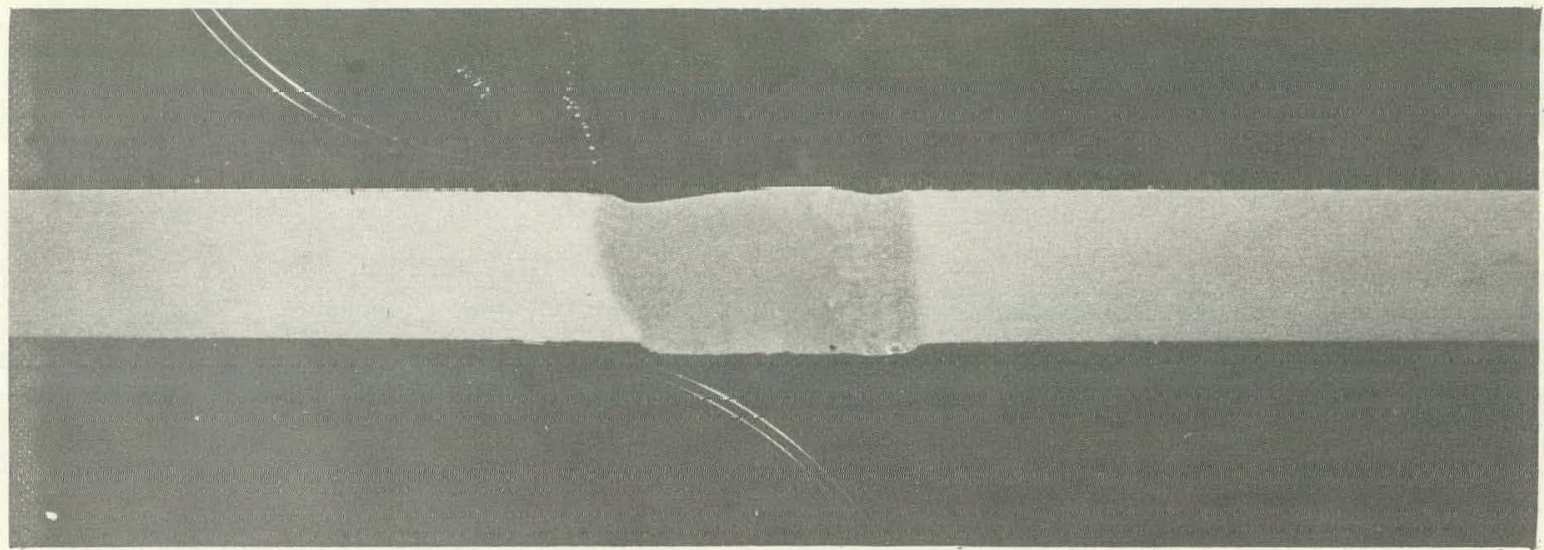

L308-1A

Figure 7. ONE-PASS, AUTOGENOUS, GAS TUNGSTEN-ARC WELD IN 1.52-mm (60-mil)-THICK TYPE 5083 ALUMINUM. [Weld was Made with Direct Current, Straight Polarity, Using Helium Shielding at $130 \mathrm{~A}$ and a $12.7-\mathrm{mm} / \mathrm{s}$ (30-ipm) Part Travel Speed; 10X)

geometry is seen in Figure 8. Table 4 gives the mechanical properties that resulted from the welding methods and also the base-metal properties. The yield strength of the welds is not significantly different nor reduced from the base-metal value. The tensile strength of the autogenous, gas tungsten-arc and electron-beam welds compares favorably with the value for the base metal. Weld-joint efficiency of the arc weld is $93 \%$; that of the autogenous electron-beam weld is $97 \%$. The electron-beam, multipass, wire-fed weld-joint efficiency drops to approximately $74 \%$. All the specimens were tested in the as-welded condition, with no dressing of the top and bottom surfaces.

\section{Comparison of Magnesium Losses to the Welding Method}

The effects of electron-beam and gas tungsten-arc, multipass, autogenous welds in deleting magnesium in Type 5083 aluminum was determined for comparison to electron-beam, wire-fed welds. Full-penetration welds were made on 2.03-mm (80-mil)-thick plates. Two to four weld passes were then staggered on top of each other. The electron beam welds were made in an approximate vacuum of $13 \mathrm{mPa}\left(10^{-4} \mathrm{~mm}\right) \mathrm{Hg}$, while the arc welds were made at 


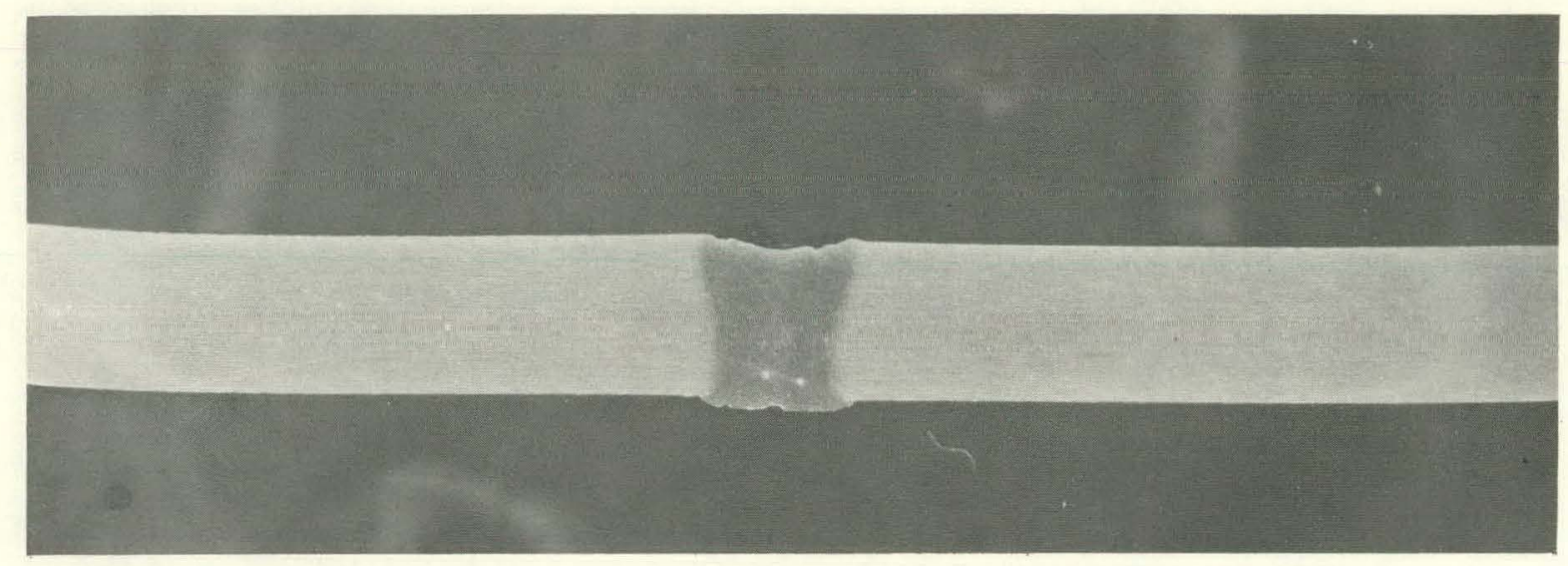

L410-3

Figure 8. ONE-PASS, AUTOGENOUS, ELECTRON-BEAM WELD ON 1.52-mm (60-mil)-THICK TYPE 5083 ALUMINUM. (The Beam was Oscillated Longitudinal to the Direction of the Welding; 10X)

Table 4

COMPARISON OF WELDING METHODS TO RESULTING MECHANICAL PROPERTIES FOR 1.52-mm (60-mil) T'YPE 5083 ALUMINUM

\begin{tabular}{|c|c|c|c|c|}
\hline \multirow[b]{2}{*}{ Welding Method } & \multicolumn{2}{|c|}{$\begin{array}{c}\text { Tensile } \\
\text { Strength(1) } \\
\end{array}$} & \multicolumn{2}{|c|}{$\begin{array}{c}\text { Yield } \\
\text { Strength }\end{array}$} \\
\hline & (ksi) & $(\mathrm{MPa})$ & (ksi) & $(\mathrm{MPa})$ \\
\hline Base Metal & 46.3 & 319.5 & 21.2 & 146.3 \\
\hline GTA (one-pass, autogenous) (2) & $43.0^{(3)}$ & 296.7 & 22.0 & 151.8 \\
\hline $\begin{array}{l}\text { Electron Beam (one-pass } \\
\text { autogenous) }\end{array}$ & $4 b . u^{(3)}$ & 310.5 & 21.4 & 147.7 \\
\hline $\begin{array}{l}\text { Electron Beam (one-pass, } \\
\text { autogenous; two wire-fer } \\
\text { passes) }\end{array}$ & $34.0^{(4)}$ & 235.6 & 20.0 & 138.0 \\
\hline
\end{tabular}

(1) Specimen dimensions were $12.7 \mathrm{~mm}(1 / 2 \mathrm{in})$ in width and $50.8 \mathrm{~mm}(2$ in) in length, except base-metal specimens which were machined T4 specimens.

(2) GTA weld was direct current, straight polarity using helium shielding.

(3) Failure was in the weld or at the bond line.

(4) Failed in the weld.

atmospheric pressure. Figure 9 reports the magnesium losses in the welds. A one-pass, electron-beam weld had approximately a $1 \%$ loss in magnesium. At the tie-in or overlap area in a weld, the loss in magnesium resultıng from two weld passes could be approximately $2.5 \%$. The weld on the $1.02-\mathrm{mm}(40-\mathrm{mil})$ root land that was used for the wire-fed weld in the 5.33-mm-thick aluminum, that was previously discussed, had an average of $2.5 \%$ magnesium, which is a deletion of magnesium greater than $2 \%$. By comparison, a small percentage of magnesium is deleted by autogenous arc welding. Figure 10 provides a comparison of the mechanical properties to the magnesium content of arc welds in Type 5083 aluminum. The curves peak at approximately $5 \%$ magnesium. The curves show a reduction in mechanical properties with a corresponding reduction in the magnesium content. 


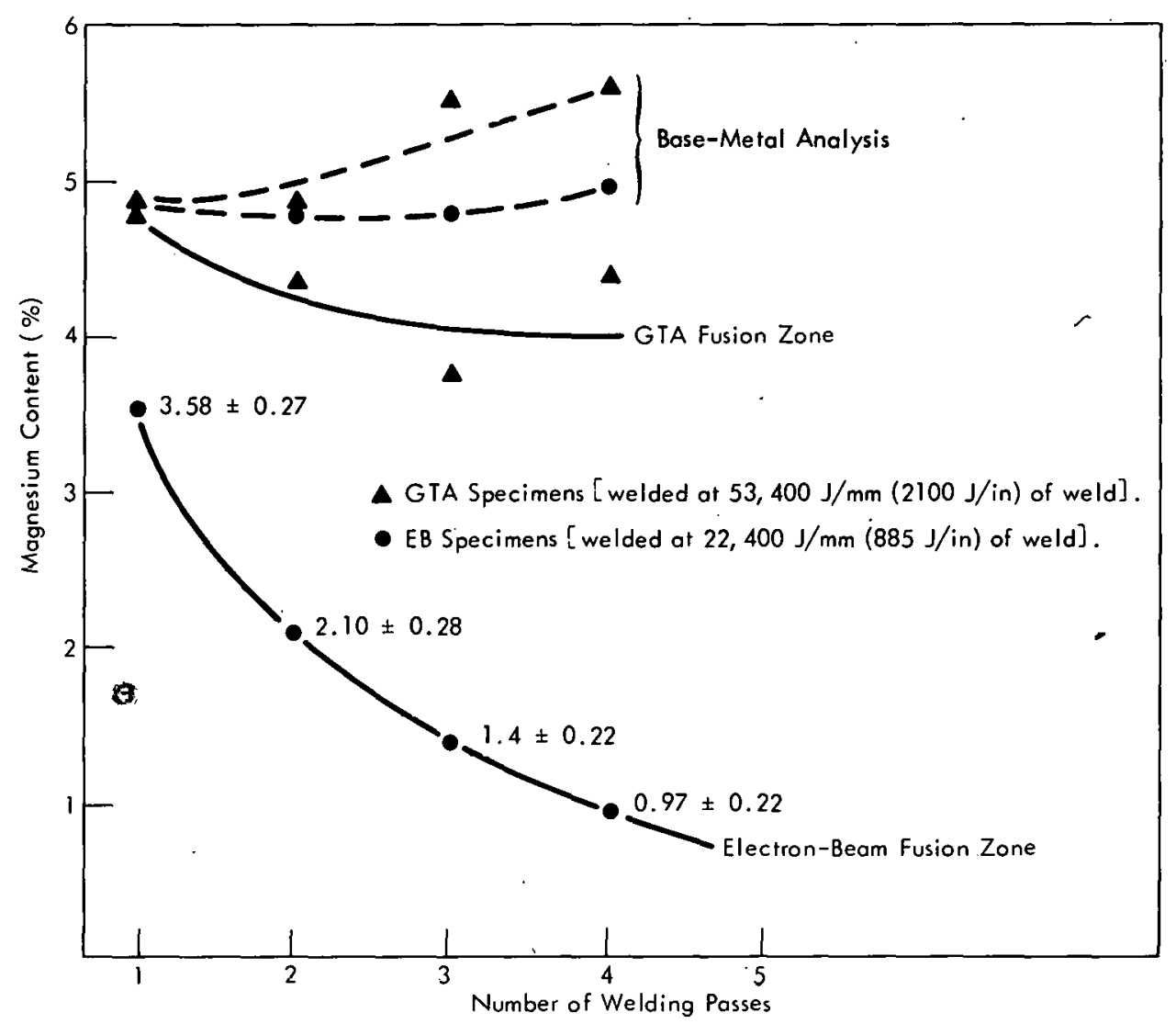

Figure 9. EFFECT ON THE ALLOY CONTENT OF AUTOGENOUS, MULTIPASS WELDS IN TYPE 5083 ALUMINUM ALLOY PLATE OF 2.03-mm (80-mil) THICKNESS.

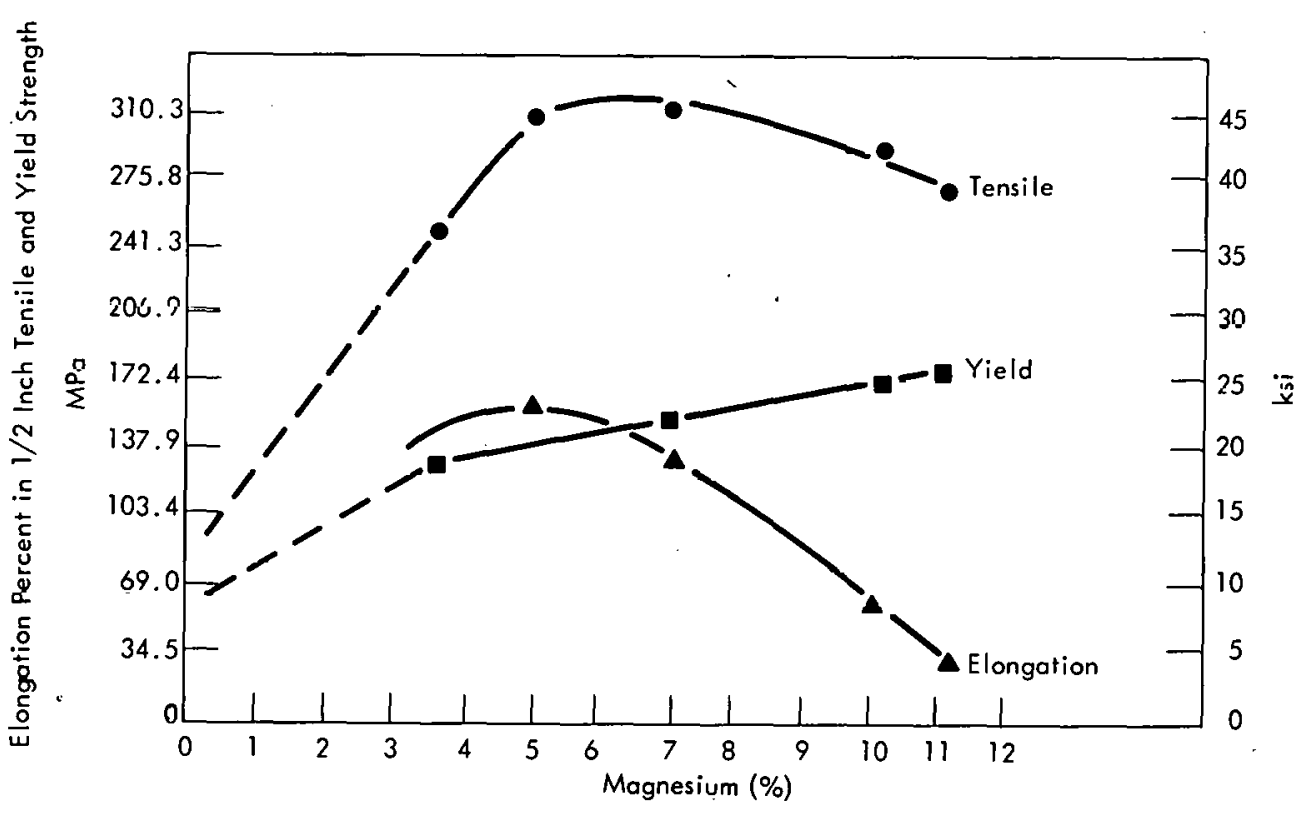

Figure 10. TENSILE PROPERTIES OF GAS TUNGSTEN-ARC WELDS IN . TYPE 5083-H113 ALUMINUM ALLOY USING FILLERS WITH VARIOUS MAGNESIUM CONTENTS. (From Welding Kaiser Aluminum, First Edition, Page 9-4; Kaiser Aluminum, Oakland, California) 


\section{Porosity in Multipass, Wire-Fed Welds}

The electron-beam, multipass, wire-fed welds generally had less porosity compared to single-pass, autogenous, electron-beam and arc welds. A typical wire-fed weld in 5.33-mm-thick aluminum, using Type 5356 aluminum wire, might have several $508-\mu \mathrm{m}$ (20-mil)-diameter pores and several pores in the 254 to $381-\mu \mathrm{m}$ (10 to 15-mil)-diameter range, as determined by radiographic inspection. The base metal and wire were cleaned by, first, degreasing; followed by a scrubbing with steel wool; followed by a wipe with a cloth moistened with alcohol. Good results were also obtained using chemically cleaned welding wire. Experience with electron-beam, multipass, wire-fed welding the 1.52-mm-thick aluminum has shown that porosity is extremely small [generally $<127 \mu \mathrm{m}$ (5 mils) in diameter] and therefore not readily detectable by radiographic inspection, Occasionally, porosity up to $254 \mu \mathrm{m}$ (10 mils) in diameter will occur. By comparison, gas tungsten-arc welds in the 1,52-mm-thick aluminum had un to seven pores that were up to $635 \mu \mathrm{m}$ (26 mils) in diameter in $25 \mathrm{~mm}$ of weld. Many single-pass, autogenous, electron-beam welds contain no detectable porosity, while other welds will contain numerous pores in the 254- $\mu \mathrm{m}$ (|Uं-mil)-diameter range, with occasional larger pores up to $635 \mathrm{\mu m}$ (25 mils) in diameter. Several reasons for reduced porosity in multipass welds are apparent: (1) the depth of weld that is deposited in each weld pass can be controlled, thereby controlling the maximum pore size; (2) a part of each preceding weld pass is remelted and refined in the vacuum of the electron-beam machine; (3) it is postulated that hydrogen is liberated from the welding wire when it is melted and allowed to escape; (4) the weld is deposited into an open groove, and this may also be beneficial to permit hydrogen to escape from the molten weld.

\section{DISCUSSION OF RESULTS}

Electron-beam, multipass, wire-fed welding is presented as a useful process to weld thick or thin aluminum. The advantages resulting trom using this process are: (1) reduced distortion Inslde the root face and base metal, and high-quality welds; (2) the process is useful in controlling porosity to a minimum number and size; (3) electron-beam welding offers precise control of the energy input to the root weld and subsequent fill passes. The principal disadvantage of the process is the reduction in weld-joint efficiency that results from the deletion of magnesium from the welding wire and base metal. The yield strength is not significantly affected by the deletion of magnesium, as was nnterd in Tables 2 and 4 ; however, the tensile strength is reduced to a value ranging from $234.6 \mathrm{MPa}$ (34 ksi) (see Table 4) to $255.3 \mathrm{MPa}(37 \mathrm{ksi}$ ) (see Table 2). It may be possible to develop welding wires that have particular chemistries to increase the as-deposited strength of electron-beam, wire-fed welds in Type 5083 aluminum alloy. Faster welding speeds during the wire-fed fill passes, combined with taster wire feed rates, may also improve the welds. The wire-fed welds have mechanical properties comparable to the arc welds that have a magnesium content close to $4 \%$ (see Figure 10). Therefore, some deletion of magnesium does not seriously degrade the tensile strength of electron-beam autogenous or wire-fed welds. Table 4 shows that the electron-beam autogenous weld had a higher tensile strength than the arc weld, while Figure 9 shows that the electron-beam weld had a magnesium content of approximately $3.6 \%$. A judgment of the importance and amount of the deletion of magnesium from electron-beam welds should be based on the particular welding procedure and application for the weld. The data presented in this work show that weld-joint 
efficiency can be reduced in Type 5083 aluminum. with improper electron-beam welding techniques.

Cold shuts are not generally a problem in electron-beam, multipass welds because the deep-penetration welds that are typically done in one weld pass are replaced by numerous weld passes. However, the prevention of cold laps requires attention in electron-beam, multipass welds as it does in any multipass welding method. Cold laps are not a problem if the welding procedure is directed toward adequate interpass fusion. The depth-to-width ratio of multipass welds compare favorably to a one-pass weld. The weld that is shown in Figure 2 has a depth-to-width ratio approaching 3 to 1. 


\section{REFERENCES}

(1) Hicken, G. K. and Booco, W. G.; "Penetration Variations in Electron Beam Welding", Third International Conference on Electron and Ion Beam Science and Technology, $\mathrm{p}$ 398; John Wiley and Sons, Inc, New York, NY (1968).

- (2) Huber, R. A. and Turner, P. W.; "Electron Beam Welding at the Oak Ridge Y-12 Plant", Welding Journal, 48, (10); pp 787-799; October 1969.

(3) Sandstrom, D. J., Buchen, J. F., and Hanks, G. S.; "On the Measurement and Interpretation and Application of Parameters Important to Electron Beam Welding", Welding Journal, 49, (7), pp 293-s to 300-s, Research Supplement.

(4) Armstrong, R. E.; "Control of Spiking in Partial Penetration Electron Beam Welds", Welding Journal, 49, (8), pp 282-s to 388-s, Research Supplement.

(5) Bradburn, E. H., Huber, R. A., and Turner, P. W.; "Multipass Electron Beam Welding for Controlled Penetration", Welding Journal, 50, (4), pp 190-s to 193-s, Research Supplement.

(6) Weber, C. M., Funk, E. R., and McMaster, P. C.; "Penetration Mechanism of Partial Penetration Electron Beam Welding", Welding Journal, 51, (2), pp 114-s to 119-s, Research Supplement.

(7) Weidner, C. W. and Shuler, L. E.; "Effect of Process Variables on Partial Penetration Electron Beam Welding", Welding Journal, 52, (3), pp 114-s to 119-s, Research Supplement.

(8) Mara, G. L., Funk, E. R., McMaster, R. C., and Pence, P. E.; "Penetration Mechanisms of Electron Beam Welding and the Spiking Phenomenon", Welding Journal, 53, (6), pp 246-s to 251-s, Research Supplement.

(9) Murphy, J. L. and Turner, P. W.; Filler-Wire Feeder and Positioner for Electron Beam Welding, Y-1932; Union Carbide Corporation-Nuclear Division, Oak Ridge Y-12 Plant, Oak Ridge, Tennessee, February 22, 1974. Available from the National Technical Information Service, US Department of Commerce, 5285 Port Royal Road, Springfield, Virginia 22161.

(10) Bench, F. K. and Ellison, G. W.; "EB Welding of 304L Stainless Steel with Cold Wire Feed", Welding Journal, 53, (12), pp 763 - 766; December 1974.

(11) Murphy J. L. and Turner, P. W.: "Wire Feeder and Positioner for Narrow-Groove Electron Beam Welding", Welding Journal, 55, (3), pp 763 - 766; March 1976

(12) Burkhardt, J. H., Jr, Davenport, C. M., and Gray, D. H.; Automatic Programmer for an Electron Beam Welder, Y-1878; Union Carbide Corporation-Nuclear Division, Oak Ridge Y-12 Plant, Oak Ridge, Tennessee, March 14, 1973. Available from National 
Technical Information Service, US Department of Commerce, 5285 Port Royal Road, Springfield, Virginia 22161.

(13) Aluminum Company of America; Welding Alcoa Aluminum, p 238; Pittsburgh, Pennsylvania. 
Distribution

Energy Research and Development Administration - Oak Ridge

Hickman, H. D.

Leed, R. E.

Zachry, D. S., Jr

Lawrence Livermore Laboratory

Nelson, W. E.

Robbins, J. L.

\section{Los Alamos Scientific Laboratory}

Hoyt, H. C.

Sandstrom, D. J.

Oak Ridge Gaseous Diffusion Plant

Stief, S. S.

Wilcox, W. J., Jr

Oak Ridge National Laboratory

Slaughter, G. M.

Weir, J. R., Jr

Oak Ridge Y-12 Plant

Alvey, H. E.

Armstrong, R. C.

Bernander, N. K.

Burditt, R. B.

Burkhart, L. E.

Dodson, W. $\mathrm{H}$.

Duggan, H. G.

Ebert, T. H.

Ellingson, R. D.

Fraser, R. J.

Gritzner, V. B.

Jackson, V. C.

Juries, F. W.

Kahl, K. G.

Keith, A.
Kite, H. T. (5)

Mills, J. M., Jr

Murphy, J. L. (10)

Phillips, L. R.

Schreyer, J. M.

Smith, H. F., Jr

Smith, R. D.

Stoner, H. H.

Tewes, W. E.

Tilson, F. V.

Townsend, A. B.

Weathersby, W. E.

Williams, R. D.

Yaggi, W. J./Googin, J. M.

$Y-12$ Central Files (master copy)

$Y$-12. Central Files (route copy)

$Y-12$ Central Files ( $Y$-12RC)

$Y-12$ Central Files (5)

Zerby, C. D.

Paducah Gaseous Diffusion Plant

Levin, R. W.

Rockwell International - Rocky Flats

Wiederecht, D. A.

Sandia - Albuquerque

Davis, M. J.

Sandia - Livermnre

Adolphson, D. R.

Union Carbide Corporation-Parma

Research Center

C'hambers, W. E.

University of Têmlesset-Culleye

of Engineering

Stansbury, E. E.

In addition, this report is distributed in accordance with the category UC-38, Engineering and Equipment, as given in the USERDA Standard Distribution Lists for Unclassified Scientific and Technical Reports, TID 4500. 